\title{
Consumer Power in the Digital Age in China Travel Market and the Strategic Management Trend in China Online Travel Industry
}

\author{
A. P. MA \\ Beijing International Studies University, Beijing, China \\ L. BAI \\ Nottingham Trent University, Nottingham, UK \\ H. W. LUO \\ China Ministry of Industry and Communications, Beijing, China \\ Y.J. Liao \\ Beijing International Studies University, Beijing, China
}

\begin{abstract}
With the rapid development of China's economy, China's tourism market entered into a stage of great development. The popularity of the Internet makes people more and more incline to use the Internet to buy travel products, Chinese consumers' purchasing power to be reckoned seriously in the digital age, huge potential tourism market with diversity need to be explored. In such a background, Chinese online travel companies must comply with the demand in age of the Internet and have a good grasp of the whole tourism market, online enterprises themselves should do some adjustment on the strategic management accordingly as well. By using the theory of four consumer power source theories, the paper discusses the dramatic structure change in China Travel service industry and the development of latest trends of online travel service companies in China.
\end{abstract}

KEYWORD: China travel market; Consumer power in the digital age; China online travel industry; strategic management

\section{BACKGROUND OF DISCUSSION}

\subsection{China travel market}

China travel market is very important due to its market size and influence in society at both domestic and abroad nowadays. The number of domestic, outbound and incoming tourists will reach 3.6bilion, 0.114 billion and 0.128 billion respectively in 2014 in China. China became No 1 in terms of outbound tourism International Tourism Expenditure by country, exceeding Germany and United States since 2011 according to World Tourism Organization. Tourism becomes an important component of modern service industry in China.

\subsection{Internet users}

China also owns the largest internet users in the World. In the digital age, consumer's power increases as the asymmetry in information between suppliers and travelers changed due to the application of a variety of information technologies.

\subsection{Research questions}

The research questions for the paper are: What's the essence of the change of consumer power in travel market in digital age theoretically from marketing management perspective? How the related consumer power in China causes the reaction of strategic management now and its trend in China online travel industry?

\section{USING FOUR CONSUMER POWER THEORY}

\subsection{Sources of consumer power changes}

According to research, power is a key human concern and constitutes a fundamental component of social systems and hierarchies (Lauren I. Labrecque, 2013). For example, the design of online search algorithms will influence what information consumers could obtain. The power between consumer and marketers will influence what and how the consumer can have their products in travel and tourism market. The team of Lauren I. Labrecque's research in 2013 summarized the four sources of consumer power changes: in demand, information-based, network-based and Crowd-based field. In demand source, Internet and social media technologies have aggregated impact of consumption and purchase behaviors, Search engines allowed increased consumer access and choice; in information-based source, under content 
consumption, consumers could have easy access to product and service information, which will "reduces information asymmetry, accelerates market diffusion of information and shortens product lifecycles". Network-based power through online network such as blog, can add value, beyond that of the original content. Crowd-based power creates the ability to pool, mobilize, and structure resources such as through crowdfunding.

\subsection{Changes in China travel industry}

By taking these four resources as the theory foundation, the paper discuss the influence of this consumer power transfer in information age in China travel industry, which causes dramatic structure change in China travel company industry in product and service offerings, heavy investment input to online travel business from both home and abroad in China since 2014.

\section{THE DEVELOPMENT OF CHINA ONLINE TRAVEL SERVICES}

\subsection{China travel services company development history}

Travel services companies developed fast since the opening policy and especially after 90s in China. There are now over 20,000 travel services in China, among which some of them run outbound businesses. The products they offered traditionally focus on package tours for both incoming and domestic tourists. Within recent several years, however, the package products couldn't meet the requirements of many people travelling as individual or visiting friends and relatives or for business or mission purposes. The breakthrough comes from one pioneering online travel company called Ctrip, it provides online hotel and air tickets bookings to many individual travelers in China in the middle 90s, by doing so , the company could be listed on New York stock exchange for reasons of representing the future of China's huge online travel e-commerce and becomes very successful. Ctrip sees the gap of dis-connectivity of computer reservation systems between hotels and airlines and meets the demand in between. The success of its business also comes from the possibility of more and more people could easily have their booking through telephones, computers and mobile phones.

\subsection{Online travel services in China}

After Ctrip, online travel services are booming in China nowadays. In addition to those 20,000 traditional off-line travel services in operation, more and more online travel services originated, Besides, the traditional offline travel services also have their online websites and channels at the same time. There is hot debate of competition between the traditional travel services and online travel services (OTA).

Travel and tourism industry in nature is information-based by providing services out of the movements of people. As the digital age enables the easy access of travelers to look for information and related booking online or through mobile phone, more and more people tend to travel without package tour and choose destinations and services by themselves. In other words, consumer power ,based on information technology, changes the structure of the product offerings in travel services industry in China dramatically at present.

The trend accelerates now in China due to the input of online investment from outside traditional travel industry and many investment from capital abroad. Two big evidences come from two richest people in China. The first one is Wang Jianlin, he with his company from real estate, has bought 7 travel agencies in China now, the other one comes from famous person Jack Ma ( Ma Yun), as his company Alibaba listed on New York exchange several month ago. Alibaba company provides an online business platform between millions of small and middle business companies and individuals doing business online in China. Alibaba also sees the potential and influence of online travel market and related business and quickly entered into online travel market during recent several months in 2014. Not only Alibaba, the other internet company, Baidu, Chinese version of google, and Tencent, its major product is wechat, the Chinese version of facebook, enter into online travel market recently. People called these three big influencers in China information industry BAT, Baidu, Ailibaba and Tencent respectively. As some of these three already with foreign capital input from foreign stock exchange market, the Chinese travel services industry becomes more and more internationalized by considering the permissions of foreign investment into travel services industry in China only several years ago due to the promise of opening market in travel business after China entering into World Trade Organization about 10 years ago. We can see the fierce competition in China travel service industry from and between both traditional offline travel services and online travel Services, as well as competition between native and foreign companies in near future .

\section{CONCLUSION}

This paper discusses the topic from the angle of how information technology deeply influences a heavy information-based industry--travel and tourism industry in China. Information technology changes the asymmetry of information between suppliers and 
travelers. Consumers in digital age in China could have more products available especially through the sources of their informational power by using a variety of hard and soft information facilities. The internet technology and mobile facilities changes the travel service industry now and in particular the future structure of product offerings and the industry itself.

Future research should focus more on the information advantages brought to suppliers as well.

How travel services make use of traveler online information to in turn provide better services and create value for both customers and company is a topic for future discussion.

The changes and opportunities due to both information technology and open global operation context in China travel industry attract foreign investment in this field in China now, which will also provide more benefits to consumers as well.

\section{ACKNOWLEDGMENTS}

This article is part of the works of tourism branding, Art performance and Tourism international communication strategy programs. The sponsorship and support comes from research programs: Beijing Tourism Branding Building, 395002(3), Beijing Cultural Performance Industry and Tourism Industry (14JGB026) and Beijing Tourism International Image Integrated Marketing and Communication Strategy (395001).

\section{REFERENCES}

[1] Lauren I. Labrecque ,\& Jonas vor dem Esche \& Charla Mathwick \&Thomas P. Novak \& Charles F. Hofacker, Consumer Power: Evolution in the Digital Age, Journal of Interactive Marketing , 27 (2013):257-269.

[2] Pradeep Racherla, Wesley Friske, Prceived 'usefulness' of online consumer reviews: An exploratory investigation across three services categories, Electronic Commerce Research and Applications, 11 (2012): 548-559. 